\title{
New financial arrangements for Nursing Students
}

You will all be aware that the Chancellor of the Exchequer presented his Comprehensive Spending Review on $27^{\text {th }}$ November 2015 (HM Treasury 2015). He set out the long term economic plan to run a healthy economy, reduce government debt and return the country to surplus. Part of the plan is to give NHS England $£ 10$ billion more a year in real terms by 2020 than in 2014-15. In addition to more treatments and tests, GP services to be open evenings and weekends, 7-day access to hospital services by 2020 and an integrated health and social care service, grants for health students will be replaced by student loans. This will mean that health students will be able to receive $25 \%$ more financial support than currently. So, what does this mean in real terms for the new recruits? You can see that Figure 1, column 1 shows the regular student loan for current non healthcare students on a 30 week programme.

\section{Finance until end of the 2016-17 Academic year through NHS Bursaries:}

Up until September 2017, for the majority of 'home status' students normally living in England and on courses eligible for an NHS bursary, have their tuition fees paid for them directly by the NHS and they are eligible to apply for a grant of $£ 1000$ which is not income assessed (NHSBSA 2016). Additionally, students living away from the parental home may be eligible for a means tested bursary of up to $£ 2643$ for a 30-week programme (dependent on parent or partner income) and for nursing and other programmes of 52 week duration, students would be eligible for an additional $£ 1848$ (ie $£ 84 \times 22$ weeks). They may also be eligible for a maintenance loan of $£ 2324$ to help pay for their living expenses (see figure 1 , column 2).

\section{Finance from September 2017}

For those students who begin their programme in September 2017, the system will change and students will be eligible to apply for a student loan, just as all other students at university. This means that students will take out a loan to pay for their tuition fees (maximum $£ 9000$, payable directly to the University) and a maintenance loan for their living expenses such as rent, food, books, travel. The maintenance loan will depend on where they are living and the data in figure 1 are based on a first year student living away from the family home but not in London.

Figure 1: Comparison of student loan funding 2016/17 with NHS Bursary funding with projected figures for student loan funding for 2017/18 for healthcare students.

\begin{tabular}{|c|c|c|c|}
\hline & $\begin{array}{l}\text { Student loan } \\
\text { funding for } 2016 / 17 \\
\text { on the basis of less } \\
\text { than } £ 25 k \text { income } \\
\text { over a } 30 \text { week } \\
\text { course } \\
\text { (non-healthcare) }\end{array}$ & $\begin{array}{l}\text { NHS Funding for } \\
2016 / 17 \text { on the } \\
\text { basis of less than } \\
£ 25 k \text { income over a } \\
52 \text { week course } \\
\text { (nurses and } \\
\text { healthcare } \\
\text { students) }\end{array}$ & $\begin{array}{l}\text { Forecasted NHS } \\
\text { Funding for } 17 / 18 \\
\text { on the basis of less } \\
\text { than } £ 25 k \text { income } \\
\text { over a } 52 \text { week } \\
\text { course } \\
\text { (nurses and } \\
\text { healthcare } \\
\text { students) }\end{array}$ \\
\hline Fee Loan & $£ 9000$ & $£ 0$ & $£ 9000$ \\
\hline Maintenance Loan & $£ 8200$ & $£ 2324$ & $\begin{array}{l}£ 10,136 \text { (£8200 (30 } \\
\text { weeks) + £88x22 }\end{array}$ \\
\hline
\end{tabular}




\begin{tabular}{|l|l|l|l|}
\hline & & & weeks = 52 weeks) \\
\hline $\begin{array}{l}\text { OR Maintenance } \\
\text { Loan for students on } \\
\text { benefits }\end{array}$ & $£ 9347$ & $£ 2324$ & $\begin{array}{l}£ 11,283 \text { ( } 19347+ \\
£ 88 \times 22 \text { weeks) }\end{array}$ \\
\hline $\begin{array}{l}\text { NHS Bursary (30 } \\
\text { weeks means tested) }\end{array}$ & $£ 0$ & $£ 2643$ & $£ 0$ \\
\hline $\begin{array}{l}\text { NHS Bursary } \\
\text { (additional weeks to } \\
\text { bring up to 52 span) }\end{array}$ & $£ 0$ & $\begin{array}{l}£ 1848(£ 84 \times 22 \\
\text { weeks) }\end{array}$ & $£ 0$ \\
\hline $\begin{array}{l}\text { NHS Bursary (non- } \\
\text { means tested) }\end{array}$ & $£ 0$ & $£ 1000$ & $£ 0$ \\
\hline $\begin{array}{l}\text { Example of individual } \\
\text { universities offering } \\
\text { their own bursaries) }\end{array}$ & $£ 1300$ per year & $£ 0$ & Yet to be decided \\
\hline
\end{tabular}

NHSBSA $(2016,2015)$

The maintenance loan for healthcare students is forecast for $2017 / 18$ at a total of $£ 10,136$ which includes the 30 week rate (for non healthcare students) of $£ 8200$, plus $£ 88$ per week for the additional 22 weeks, for their 52 week programme (see figure 1, column 3).

Further support is normally available for students with dependents (both adult and children) together with funding to assist with Ofsted Registered Childcare. These are means tested and based on the number of dependents plus the level of childcare usage.

\section{Repayment}

Repayment of student loans will only require to be repaid once students have completed their programme and when they are in paid employment (Student Finance England 2016). Students' income needs to be over $£ 404$ per week or $£ 1750$ per month or $£ 21,000$ per year before being eligible to repay. The amount they pay will depend on what they earn, not on what they borrowed and will be deducted by their employer at $9 \%$ of their income above these thresholds. If their income falls below these thresholds or stops, then their repayment will also stop. So, for example, newly qualified nurses earning $£ 21,700$ will repay around $£ 5.25$ per month (DH 2016). There are other special entitlements if they have special circumstances.

So, in essence student nurses and other healthcare professional students commencing in September 2017 will be eligible for more financial support than ever before and be expected to repay this at a rate far easier than any bank loan.

The question for me is that there are many inaccuracies being talked about among the student body as to what the future might hold and I hope that these facts dispel any concerns that both school leavers and mature students might have in pursuing their career of choice. We often find that current nursing students struggle financially during their course and the new system of student loans will increase their living cost support, so benefitting them while they study. Apart from Scandinavia, most countries in the Western world expect nursing students to pay for their education, so the UK will align themselves with most others across the world. Undoubtedly the reforms to healthcare education funding will allow greater investment in the NHS itself, reduce the central control in managing and reporting the healthcare students and allow more of the tuition fees to be invested by universities in the delivery of quality programmes. 
References

Department of Health (2016) Reforming healthcare education funding: creating a sustainable future workforce. April. Accessed on 29.4.16 at

https://www.gov.uk/government/consultations/changing-how-healthcare-education-is-funded

National Health Service Business Services Authority (2016) Financial Help for Healthcare Students 2016/17. Accessed on 5.5.16 at

http://www.nhsbsa.nhs.uk/Students/Documents/Students/Financial help for healthcare stu dents 2016-17 (V1) 04.2016.pdf

National Health Service Business Services Authority (2015) Financial Help for Healthcare Students 2015/16. Accessed on 5.5.16 at

http://www.nhsbsa.nhs.uk/Students/Documents/Students/Financial help for healthcare students 20 15-16 (V2) 08.2015.pdf

Student Finance England (2016) Student Loans: a guide to terms and conditions 2016/17 https://www.saas.gov.uk/ forms/slc terms conditions.pdf 